\title{
The Relationship between Ventilation with Excess Cancer Risk (ECR) of Benzene at the Shoe Home Industry in Romokalisari Surabaya
}

\author{
Bachtiar Chahyadhi, Abdul Rohim Tualekaı \\ IDepartment of Occupational Health and Safety, Faculty of Public Health, Airlangga University, Surabaya
}

\begin{abstract}
The objectives of this study were to identify the relationship of Ventilation with Excess Cancer Risk (ECR) of benzene at the shoe home industry in Romokalisari, Surabaya. This researchwas observational, cross-sectional study 10 workers as the total population.

The data was analysed using cross tabulation to calculate the frequency of Ventilation and Excess Cancer Risk (ECR), that obtained from the value of benzene Carcinogen Intake (Ink), benzene concentration in work environment $(\mathrm{C})$, worker's weight $(\mathrm{Wb})$, inhalation rate $(\mathrm{R})$, length of work/day (tE), working frequency/year (fE), duration of work (Dt), and average time period $\left(\mathrm{t}_{\mathrm{avg}}\right)$. Analysis relationship between Ventilation with Excess Cancer Risk (ECR) of benzene carcinogen was using Coefficient-Contingency Test and Prevalence Risk (PR).

From observation it was found that most of the workplace were not ventilated (9 places/90\%). Concentrations of benzene $0.04 \mathrm{mg} / \mathrm{m}_{3}-2.91 \mathrm{mg} / \mathrm{m}_{3}$, inhalation rate (R) $0.5 \mathrm{~m}_{3} / \mathrm{hr}-0.7 \mathrm{~m} 3 / \mathrm{hr}$, length of work per day (tE) 8 hours/day-15 hours/day, working frequency (fE) 312-365 days/year, duration of work (Dt) 14 - 43 years, weight of worker's $(\mathrm{Wb})$ in 8 people $(80 \%) \leq 70 \mathrm{Kg}$, CSF benzene $0.055 \mathrm{mg} / \mathrm{m}_{3}$, and excess cancer risk $(\mathrm{ECR})>10-4$ indicated that there was a possibility of carcinogenic health risks. P-value was 0.035 , meaning there was a relationship between the existence of ventilation with the Excess Cancer Risk (ECR) of benzene carcinogen in workers. Prevalence Risk (PR) was 9.0, meaning that the absence of ventilation has a 9 times greater risk of carcinogen health effects. Recommendations were by providing better ventilation in the workplace, consuming CYP2E1 enzyme contained in cow liver and salmon to lower benzene concentration in the body, it is necessary for risk management to include medical tests, added air vents, replaced with safer materials, and communicated to use personal protective equipment. 12,16
\end{abstract}

Keywords: Benzene, Ventilation, Excess Cancer Risk(ECR),Shoes Home Industry

\section{INTRODUCTION}

The use of chemicals in the informal industry sector was significantly increasing. One of the informal sectors that use chemicals was home industry such as shoes or sandals industry that uses glue materials in their production process. In general, glue or adhesive contains

\section{Corresponding Author:}

Abdul Rohim Tualeka

Department of Occupational Health and Safety, Public Health Faculty, Airlangga University, Kampus C, Jalan Mulyorejo, Surabaya, 60115, Indonesia

Tel: +62 81335519732

E-mail: inzut.tualeka@gmail.com a variety of mixtures including benzene and toluene which act as a solvent. Benzene is well known as a good organic solvent for various industrial processes such as rubber industry, shoes, paint solvents, components in motor fuel, component in detergents, pesticides and pharmaceutical manufacturing. 8

Based on Regulation Ministry of Manpower and Transmigration No Per.13/MEN/X/2011 about Threshold Limit of Physical Factor and Chemical Factors at Work, maximum benzene exposure is at 1.59 $\mathrm{mg} / \mathrm{m}_{3,11}$ continuous exposure to benzene and exceeding predetermined threshold values can cause adverse health effects, especially exposure through inhalation. The impacts that can arise from acute exposure to benzene 
were disruption of the nervous system, lack of oxygen supply to the brain, dizziness, rapid heartbeat, headache, tremors, confusion, and fainting. 17,18 Benzene toxicity to the central nervous system arises after exposure to benzene through inhalation/respiration with high concentrations $(3,000 \mathrm{ppm}$ for 5 minutes) or 30 to 60 minutes via digestion.3

This was in accordance with the results of a study, that conducted by Betty 4 on the health risk of benzene exposure to the worker at the leather shoes industry in Pulo gadung, Jakarta. The calculation of the carcinogen effects for exposure to lifetime and realtime concentrations of benzene at risk of adverse health effects because of the value of excess cancer risk (ECR) $>10-4$ so that it required a risk management

to protect workers in the five workshops. The exposure of safe benzene concentration for a carcinogenis 0.023 $\mathrm{mg} / \mathrm{m}_{3}$, while the benzene concentration at the shoe production place is $0.206 \mathrm{mg} / \mathrm{m}_{3}$, it is necessary for risk management to include medical tests, adding air vents, using safer materials, using food rich in glycine and using the personal protective equipment. 16

The home industry Romokalisari Surabaya were producing shoes. There is a process of gluing shoes with the use of glue materials in which there was benzene chemical content. The benefit of using ventilation in the shoes home industry Romokalisari, Surabaya was that it can decrease the level of exposure of benzene in the workplace, therefore the study aims to correlation the existence of ventilation with excess cancer risk (ECR) of benzene carcinogen in home industry Romokalisari Surabaya.

\section{MATERIALSAND METHOD}

This research was conducted on 8th of October 2017 on the gluing section of shoehome industry Romokalisari Surabaya. This research was use the cross-sectional approach. The independent variable in this study was the ventilation on the nominal measurement scale. The dependent variable is the Excess Cancer Risk (ECR) of benzene carcinogen in ppm unit. Total population counted 10 samples.

Variables in this study were the presence of ventilation and Excess Cancer Risk (ECR) of benzene carcinogen. Determination of Excess Cancer Risk (ECR) of benzene carcinogen was calculated from Intake benzene carcinogen $\left(\mathrm{I}_{\mathrm{nk}}\right)^{*} \mathrm{CFS}$. The value of Intake benzene carcinogenic was the result of calculation that was directly proportional to the value of benzene concentration in the working environment (C), inhalation rate of worker (R), length of work/day (tE), working frequency per year (fE), duration of work (Dt) and was inversely proportional to the worker's characteristic value (consisting of worker's weight $(\mathrm{Wb})$ and average time period $\left(\mathrm{t}_{\mathrm{avg}}\right)$.

Primary data collected include the presence of ventilation data and worker characteristics (worker's weight $(\mathrm{Wb})$, length of work/day (tE), working frequency every year (fE), duration of work (Dt)). Secondary data collection included benzene concentration value data in work environment (C), worker inhalation rate $(\mathrm{R})$ and average time period $\left(\mathrm{t}_{\mathrm{avg}}\right)$ used for carcinogen intake benzene $\left(\mathrm{I}_{\mathrm{nk}}\right)$ and CFS value used to calculate Excess Cancer Risk (ECR).

Data analysis was using cross tabulation to know the frequency of the presence of ventilation and frequency of value to determine Excess Cancer Risk (ECR) of benzene carcinogen that is the result of calculation from Intake benzene carcinogen $\left(I_{n k}\right)^{*}$ CFS. To determine the value of carcinogen intake benzene ( $\left.I_{n k}\right)$, it was necessary to know the frequency of benzene concentration values in the work environment (C), inhalation rate of worker (R), length of work/day (tE), frequency of work each year (fE), working duration (Dt), worker's characteristic value (consisting of worker's weight $(\mathrm{Wb})$ and average time period $\left(\mathrm{t}_{\mathrm{avg}}\right)$. The relationship analysis of the correlation of ventilation with Excess Cancer Risk (ECR) of benzene carcinogen was using Coefficient-Contingency Test and to know the amount of risk was using Prevalence Risk (PR).

\section{FINDINGS}

A. The Presence of Ventilation: Based on table. 1 below, most of the place where the workers did their gluing work in the shoes home industry of Romokalisari, Surabaya had no ventilation as many 9 places $(90 \%)$.

Table 1: Distribution of Presence of Ventilation at Worker's Place in The Shoes Home Industry of Romokalisari, Surabaya

\begin{tabular}{|c|c|c|}
\hline The Presence of Ventilation & $\mathbf{N}$ & $\mathbf{\%}$ \\
\hline Yes & 1 & 10,0 \\
\hline No & 9 & 90,0 \\
\hline Total & 10 & 100,0 \\
\hline
\end{tabular}


Based on Regulation Ministry of Health Republic Indonesia No. 48 in 2016 about Occupational Safety and Health Standards in Office, it was said that one of the requirements of building safety and security was the availability of ventilation for circulation and air exchange needs, especially when there wasa component that used asolvent such as benzene. In addition, based on decision Ministry of Health Republic Indonesia No. 1405/ MENKES/SK/XII/2002 in 2002 about the Health Working Environment Requirements in the Office and Industry, it was said that every office space and industry had of ventilation holes. Standard air exchange was $0.283 \mathrm{~m} 3 / \mathrm{min} /$ person with a ventilation of rate are 15 to $0.25 \mathrm{~m} / \mathrm{s}$. For non-air conditioned working, rooms should have a ventilation hole at least $15 \%$ of the floor area by applying a cross ventilation system.10
LEED9, ASHRAE2, and $\mathrm{ICC}_{7}$, suggested that additional ventilation at the end of construction would reduced VOC concentrations (including benzene) to acceptable levels. In indoor environmental studies, BRE reported that seasonal variation in indoor air concentrations was due to higher concentrations of exterior air infiltrated to buildings, and a greater effect of indoor sources during the winter than in the summer months. This was because of the available ventilation a low/ bad level. VOC concentrations including benzene were reduced when the level of ventilation andmaterial emission standards were met.

B. Excess Cancer Risk (ECR) of Benzene Carcinogen: The following numbers on the table below were the data of benzene concentration, inhalation rate, worker characteristics, carcinogenic benzene intake and Excess Cancer Risk (ECR) in the shoe home industry of Romokalisari, Surabaya.

\section{Table 2: Data of Benzene Concentration, Inhalation Rate, Workers Characteristic, Intake Benzene Carcinogen and Excess Cancer Risk (ECR) of Benzene Carcinogen in The Shoes Home Industry of Romokalisari, Surabaya.}

\begin{tabular}{|c|c|c|c|c|c|c|c|c|c|}
\hline $\begin{array}{c}\text { No. } \\
\text { Workers }\end{array}$ & $\begin{array}{c}\mathrm{C} \\
\mathrm{mg} / \mathrm{m}_{3}\end{array}$ & $\begin{array}{c}\mathbf{R} \\
\mathbf{m}_{3} / \mathbf{j a m}\end{array}$ & $\begin{array}{c}\text { tE } \\
\text { Jam/hari }\end{array}$ & $\begin{array}{c}\mathbf{f E} \\
\text { days/year }\end{array}$ & $\begin{array}{c}\text { Dt } \\
\text { year }\end{array}$ & $\begin{array}{l}\text { Wb } \\
\text { Kg }\end{array}$ & $\begin{array}{c}\mathrm{t} \\
\text { avg } \\
\text { day }\end{array}$ & $\begin{array}{c}1 \\
\mathrm{nk} \\
\mathrm{mg} / \mathrm{Kg} / \mathrm{day}\end{array}$ & $\begin{array}{c}\text { ECR } \\
\mathrm{mg} / \mathrm{Kg} / \text { day }\end{array}$ \\
\hline 1. & 1.12 & 0.5 & 13 & 312 & 43 & 42 & 25550 & 0.09791 & 0.005385303 \\
\hline 2. & 1.12 & 0.6 & 9 & 312 & 43 & 52 & 25550 & 0.05955 & 0.003275346 \\
\hline 3. & 0.06 & 0.6 & 14 & 312 & 36 & 50 & 25550 & 0.00426 & 0.000234135 \\
\hline 4. & 0.06 & 0.6 & 8 & 312 & 40 & 48 & 25550 & 0.00277 & 0.000152429 \\
\hline 5. & 1.27 & 0.7 & 10 & 350 & 27 & 70 & 25550 & 0.04367 & 0.002401576 \\
\hline 6. & 1.27 & 0.6 & 8 & 365 & 20 & 50 & 25550 & 0.03346 & 0.001840544 \\
\hline 7. & 1.27 & 0.7 & 8 & 312 & 14 & 80 & 25550 & 0.01477 & 0.000812257 \\
\hline 8. & 1.27 & 0.6 & 15 & 365 & 23 & 53 & 25550 & 0.06959 & 0.003827613 \\
\hline 9. & 2.91 & 0.7 & 10 & 312 & 25 & 85 & 25550 & 0.07249 & 0.003986947 \\
\hline 10. & 0.04 & 0.7 & 15 & 365 & 20 & 70 & 25550 & 0.00159 & 0.000087647 \\
\hline \multicolumn{8}{|c|}{ Average } & 0.04001 & 0.002200379 \\
\hline
\end{tabular}

Table 2 above, the value of intake benzene carcinogenic $\left(I_{n k}\right)$ can be calculated using the following formula: Based on the calculation of Intake benzene carcinogen $\left(\mathrm{I}_{\mathrm{nk}}\right)$ value above, it was known that the maximum intake value received by workers in the shoes home industry Romokalisari Surabaya was $0.09791 \mathrm{mg} / \mathrm{Kg} / \mathrm{day})$.

Excess Cancer Risk (ECR) of benzene carcinogen determines benzene exposure having carcinogenic risks in the worker's body or not. The value
Excess Cancer Risk (ECR) is calculated using the following formula:

It was known that the carcinogenic benzene ECR values established by US-EPA 19 was $\left(\leq 10_{-4}\right)$ $\mathrm{mg} / \mathrm{Kg} /$ day. Based on the calculation in Table 2 above, the average value of excess cancer risk (ECR) on workers in the shoes home industry of Romokalisari Surabaya was 8 x $10_{-5} \mathrm{mg} / \mathrm{Kg} /$ day and the highest ECR was $53 \times 10_{-4} \mathrm{mg} / \mathrm{Kg} /$ day. This showed that ECR $>10_{-4}$, meaning that 
there was a possible indication of the risk of carcinogenic health effect and the need for control measures. 3

This was in accordance with the results of study that was conducted by Rendi $i_{13}$ on the health risk assessment for exposure to benzene in SPBU Pancoranmas, Depok. Fuel pump operators have a risk carcinogenic effect of each individual can be concluded that at 3 years exposure there is 1 employee who is at risk of cancer effect, and at lifetime exposure all employees are at risk of cancer. All of the population but the administrative staff was at risk of a carcinogenic effect on all the duration of exposure. It was advised that all workers should work no more than 3 years, working for a maximum of 6 hours/day or the use of appropriate PPE to protect them from the risk of cancer.

C. The Presence of Ventilation with Excess Cancer Risk (ECR)of Benzene Carcinogen: Analysis of the relationship between of ventilation with Excess Cancer Risk (ECR) of benzene, the Excess Cancer Risk (ECR) has 2 value, that were ECR $\leq$ 10-4 and ECR > 10-4, in the Prevalence Risk (PR) calculation. The following table was the relationship between of ventilation with Excess Cancer Risk (ECR) of Benzene Carcinogen.

Table 3: Relationship between of Ventilation with Excess Cancer Risk (ECR) of Benzene Carcinogen The Shoes Home Industry of Romokalisari, Surabaya

\begin{tabular}{|c|c|c|c|c|c|c|c|c|}
\hline \multirow{3}{*}{$\begin{array}{c}\text { The Presence of } \\
\text { Ventilation }\end{array}$} & \multicolumn{4}{|c|}{ Excess Cancer Risk (ECR) } & \multirow{2}{*}{\multicolumn{2}{|c|}{ Total }} & \multirow{3}{*}{$\mathbf{p}$} & \multirow{3}{*}{$\begin{array}{c}\text { Prevalence Risk } \\
\quad(95 \% \mathrm{CI})\end{array}$} \\
\hline & \multicolumn{2}{|c|}{ ECR $>10-4$} & \multicolumn{2}{|c|}{ ECR $<10.4$} & & & & \\
\hline & $\mathbf{N}$ & $\%$ & $\mathbf{N}$ & $\%$ & $\mathbf{N}$ & $\%$ & & \\
\hline Yes & 0 & 0.0 & 1 & 10.0 & 1 & 10.0 & \multirow{3}{*}{0.035} & \multirow{3}{*}{$\begin{array}{c}9.000 \\
(1.418-57.117)\end{array}$} \\
\hline No & 8 & 80.0 & 1 & 10.0 & 9 & 90.0 & & \\
\hline Total & 8 & 80.0 & 2 & 20.0 & 10 & 100.0 & & \\
\hline
\end{tabular}

The results in table 3 above, it was found that the p-value of the relationship between the Presence of Ventilation with Excess Cancer Risk (ECR) of benzene carcinogen was 0.035 and when compared with $\alpha$ that was 0.005 then $\mathrm{p}$-value 0.035 was smaller than $\alpha$ so it could be seen that there was a relationship between the presence of ventilation with Excess Cancer Risk (ECR) of benzene carcinogen in the shoe home industry of Romokalisari, Surabaya.

Prevalence Risk (PR) showed 9, meaning that the absence of ventilation was 9 times greater risk for carcinogen health effects $\left(\mathrm{ECR}>10_{-4}\right)$ to workers in the shoe home industry of Romokalisari, Surabaya and there was a significant relationship between the presence of ventilation and the value Excess Cancer Risk (ECR) to worker in the shoe home industry of Romokalisari, Surabaya which could be seen from PR value does not pass 1 (1,418-57,1117).

The results of this study showed that the ventilation system controls the exposure of benzene in the shoe industry Romokalisari Surabaya, because the ventilation system works to draw more air into the work room by using fan to encourage air to rise and can be dilutied by mixing with fresh air entering ventilation, and equipped with exhauster to suck air contaminants out the room. In addition, workers are encouraged to use personal protective equipment, especially masks, placing some plants that work to accelerate the decomposition of benzene vapor, and always maintain good hygiene, and promote healthy life style. 15

\section{CONCLUSION}

The result of the study found out that most of the places $(90.0 \%)$ for workers to work did not have ventilation. The most of worker in the shoe home industry of Romokalisari, Surabaya had Excess Cancer Risk $(80.0 \%)$ more than 1 . There was a significant relationship between the presence of ventilation with Excess Cancer Risk (ECR) of benzene carcinogen in the shoe home industry of Romokalisari, Surabaya (p-value $=0.035$, Prevalence Risk $=9.0)$. The recommendation was by making ventilation in a good workplace and by consuming CYP2E1 enzyme contained in beef liver and salmon that serves to lower benzene levels in the body, and the use of appropriate PPE to protect them from the risk of cancer.12,16 
Conflict of Interest: All authors have no conflicts of interest to declare.

Source of Funding: This is an article "The Relationship Between Ventilation With Excess Cancer Risk (ECR) of Benzene in The Shoes Home Industry of Romokalisari, Surabaya" of Occupational Health and Safety Department that was supported by Activity Budget Plans 2018, Faculty of Public Health, Airlangga University.

Ethical Clearance: The study was approved by the institutional Ethical Board of the Public Health, Airlangga University.

\section{REFERENCES}

1. ACGIH. Threshold Limit Values for chemical substances and physical agents and biological exposure indices. Cincinnati: American Conference of Governmental Industrial Hygienists; 2014. p. 1-13.

2. ASHRAE. The standard for the design of highperformance green buildings (ASHRAE 189.12014). US: ASHRAE and US Green Building Council; 2014.

3. ATSDR. Toxicological profile for benzene. USA: U.S. Department of Public Health and Human Services; 2007.

4. Betty, Susilowati. Resiko Kesehatan Terhadap Pajanan Benzema Pada Pekerja Industri Sepatu Kulit, PIK Pulogadung. Skripsi. Department of Public Health Indonesia University, Depok; 2011

5. Crump DR. Indoor air pollution. In: Davison G, Hewitt $\mathrm{CN}$, eds. Air pollution in the United Kingdom. Cambridge, UK: The Royal Society of Chemistry; 1997.

6. Hult Willem H, Price P, HotchiT, Russell M, SingerB. Formaldehyde and acetaldehyde exposure mitigation in U.S. Residences: In-home measurements of ventilation control and source control. Indoor air. Wiley Online Library. 2014; 25(5): p. 523-535.

7. ICC.Internationalgreenconstruction. Washington, DC: ICC; 2013.

8. Inoue,. Seiji,. Et al. Quantitative relation of urinary phenol levels to breathzonebenzene concentrations: a factory survey. British Journal of Industrial Medicine1986;43:692-697.

9. LEED. Rating system selection guide. Washington, DC: U.S. Green Building Council; 2016.

10. Menteri Kesehatan Republik Indonesia. Kepmenkes No. 1405/MENKES/SK/XII/2002 tentang persyaratan kesehatan lingkungan kerja perkantoran dan industri. Jakarta: Kementrian Kesehatan RI; 2002.

11. Menteri Tenaga Kerja dan Transmigrasi. Peraturan menteri tenaga kerja dan transmigrasi nomor Per.13/MEN/X/2011 tahun 2011 tentang nilai ambang batas faktor fisika dan faktor kimia di tempat kerja. Jakarta: Kemenakertrans RI; 2011.

12. Nirmawati S, TualekaAR, AdiAN. Effect of food containing high $\mathrm{Fe}$ (iron) intake to urinary trans, transmuconic acid (Tt-ma) levels on workers exposed to benzene. Indian Journal of Public Health Research \& Development. 2018; 9(1): p. 53-57.

13. Rendi Noor, Analisis Risiko Kesehatan Pajanan Benzene Pada Karyawan SPBU "X" Pancoranmas Depok. Skripsi. Kesehatan Masyarakat Universitas Indonesia Depok; 2011

14. Slorach, Stuart A. Measurement of Metabolism as Indicators of Exposure to chemicals. Methods for Assessing Exposure of Human and non-human biota. Edited by G. Tardifatand B. Goldstein. SCOPE 1991. Published by John Willey \&Sons Ltd.

15. Sri Maywati, Siti Novianti, Hubungan Faktor Pemajanan (Masa Kerja Dan Ventilasi) Dengan Kadar Fenol Urin Pekerja Bagian Pengeleman Pada Industri Sandal Kota Tasikmalaya, 2011 (jurnal).

16. Tualeka R, Irianto A, Prasetyo A, Rachmawati A, Dyah E. Detoxification Of Benzoic Acid in Workers Exposed to Toluene Using Food Rich in Glycine, Indian Journal of Public Health Research \& Development. 2018; p. 1

17. US-EPA.Carcinogenic effects of benzene: An update. Prepared by the national center for environmental health, office of research and development. Washington, DC: US EPA; 1998. US-EPA. Benzene (CASRN 71-43-2). Washington, DC: Irish, US EPA; 2015. 
19. Leeuwen CJ, Vermeire TG. Risk Assessment of Chemical: An Introduction. Dordrecht, Netherlands: Springer; 2007:23. https://doi.org/10.1007/978-1-4020-6102-8. Accessed February 15, 2018.

20. EPA. EPA's Integrated Risk Information System (IRIS) Program - progress report and report to Congress, Chapter 1 - introduction. United State of America; 2015. https://www.epa.gov/sites/produc tion/files/2015-06/documents/iris_report_to_congress_2015.pdf. Accessed May 24, 2018.

21. Azwar A. Introduction of Epidemiology. Jakarta, Indonesia: Binarupa Aksara PT; 1988:30-31. [In Indonesian]

22. Hodgson E. A Textbook of Modern Toxicology. 4th ed. USA: Wiley; 2010:3-34.

23. Kobayashi K, Pillai KS, Michael M, Cherian KM, Ohnishi M. Determining NOEL/NOAEL in repeated-dose toxicity studies, when the low dose group shows significant difference in quantitative data. Lab Anim Res. 2011;26(2):133-137. 